\title{
A Breath of Polluted Air: How Indiana's Air Pollution Policies Are ImPacting Its Citizens
}

\author{
KYLE ANDREW TUCKER*
}

\section{INTRODUCTION}

Nestled between two rivers, at the tip of Indiana's most southern point, lies Evansville, Indiana, a town of approximately 119,000 residents. ${ }^{1}$ Of those residents, resided a 12-year-old boy named Kavon Cooper who suffered from severe asthma. ${ }^{2}$ So severe that it restricted the amount of time Kavon could spend outside or whether he could stay at a friend's house overnight; because of this, Kavon spent most of his time indoors, windows shut, playing video games. ${ }^{3}$ This was his norm, at least until he collapsed and died in his home on April 18, $2015 .^{4}$ The coroner ruled Kavon's death "an acute asthma attack" and the only explanation that Kavon's mother, Kris Dasch, received was that the "pollen had spiked" that day. ${ }^{5}$ However, something else had spiked the previous day and continued to spike on the day Kavon died, it was "fine particulate matter." Fine particulate matter are tiny toxic specs that are released into the air by emissions from coal-fired power plants, vehicles, and other factories. ${ }^{7}$ According to the air monitor, less than half a mile away from Kavon's home, fine particulate matter had increased twenty micrograms per cubic meter the day before Kavon died, and then increased by an additional nine micrograms per cubic meter the next day. ${ }^{8}$ Dr. Carrie A. Redlich, director of the Yale Occupational and Environmental Medicine Program believes that air pollution was at the very least, a contributing factor in Kavon's death. ${ }^{9}$

However, Kavon Cooper's death is not an isolated one. Approximately sixtyfive miles north of Evansville, in Washington, Indiana, 3-year-old Leighton Fry suffers from chronic asthma which requires two daily breathing treatments and

* J.D. Candidate, 2020, Indiana University Robert H. McKinney School of Law-Indianapolis; B.A., 2015, Indiana University_Bloomington.

1. Quick Facts Evansville city, Indiana, U. S. CEnsus Bureau, https://www.census.gov/ quickfacts/fact/table/evansvillecityindiana/PST045218 [https://perma.cc/Q2XU-XAXK].

2. Jamie Smith Hopkins, America's Super Polluters. Many states have at least one. In southwest Indiana, there are four, CTR. FOR HEALTH JOURNALISM (Sept. 30, 2016), https://www.centerforhealthjournalism.org/fellowships/projects/america's-super-polluters [https://perma.cc/G83B-ETJ3].

3. Id.

4. Kavon Cooper, COURIER \& PRESS (Apr. 22, 2015), https://obits.courierpress.com/ obituaries/courierpress/obituary.aspx?n=kavon-cooper\&pid=174688817 [https://perma.cc/48DT9CDC].

5. Hopkins, supra note 2.

6. See id.

7. $I d$.

8. $I d$.

9. Id. 
up to five other medications. ${ }^{10}$ The Fry house is located eight miles downwind from Indianapolis Power \& Light Company's Petersburg plant in Gibson County. ${ }^{11}$ Leighton's pediatrician, Norma Kreilein, is certain that air pollution is the causation of Leighton's asthma, and also for other respiratory illnesses found in children in the area, stating " $\mathrm{t}] \mathrm{h}$, [link] is a mathematical certainty. Pollutants are inflammatory. It's the same link we see with cigarette smoke." 12

A contributing factor to air pollution in southwest Indiana are the seven coalfired power plants within the region. ${ }^{13}$ Of the seven, four are what the Center for Public Integrity have dubbed "super polluters." ${ }^{\prime 4}$ To determine a super polluter, the Center engaged in a nine-month long study that merged two federal datasets on United States air pollutants in $2014 .{ }^{15}$ Through the study, they found that out of 20,000 registered facilities, a third of all toxic air releases came from 100 facilities; and a third of all greenhouse gas emissions came from 100 facilities - with twenty-two facilities being on both lists. ${ }^{16}$ These twenty-two facilities came to be known as "super polluters." super polluters include: the Indiana-Michigan Power's Rockport plant in Spencer County, the Indianapolis Power and Light plant in Pike County, the Duke Energy's Gibson Power Plant in Gibson County, and the Alcoa and Vectren Generating Unit in Warrick County. ${ }^{18}$ Together they emit millions of tons of toxic air pollution per year; so much in fact, that activist have started referring to southwest Indiana as "the sacrifice zone."

\section{A. A Brief History of Coal}

Coal has had a deep developmental and social impact on the world and especially the United States. Prior to coal, wood was the world's primary energy source. ${ }^{20}$ But due to increased populations, development, and deforestation, wood was no longer viable, and the world transitioned to coal throughout the 19th

10. Bob Segall, 13 Investigates: Indiana's Toxic Air, WTHR (Apr. 14, 2016, 9:34 PM), https://www.wthr.com/article/13-investigates-indianas-toxic-air [https://perma.cc/9E3A-W2MN].

11. Id.

12. Id.

13. See Hopkins, supra note 2.

14. Id.

15. Id.

16. Id.

17. Id.

18. Mark Wilson, Super Polluters Tour Gives People Close Up Look at Where Hoosiers Get Their Power, COURIER \& PRESS (Aug. 17, 2018, 1:42 PM), https:/www.courierpress.com/story/ news/local/2018/08/17/southwest-indiana-power-plants-super-polluters-tour-sierraclub/1019414002/ [https://perma.cc/P2XY-J675].

19. Id.

20. Coal in the U.S. and Indiana, Ind. GeOlOGICAL \& WATER SURV., https://igws.indiana. edu/Coal/ [https://perma.cc/8NDS-8DXN]. 

ARE IMPACTING ITS CITIZENS

century. ${ }^{21}$ This transition was especially correlated to the increased number of steam-powered locomotives like ships and trains: to say, as coal consumption increased, so did the expansion of railroads and ships in the United States. ${ }^{22}$ It can most easily be seen through the production and demand for coal. For example, in 1850 , the US produced approximately 9.3 million tons of coal, this number jumped to 750 million by 1918 and by the 1940s, it was responsible for up to $75 \%$ of US energy. ${ }^{23}$ Therefore, coal has greatly influenced and is attributable to the gains in economic and social developments for the last 150 years. This is especially true in the United States simply because of its abundance. There is estimated to be 257 billion tons of coal in the US, which accounts for "more than one-fourth of the world's total known coal reserves." ${ }^{24}$ Coal seemed like a solution to all energy issues.

However, by the 1970s, air pollution in general was a noticeable problem. This led to President Richard Nixon signing the Clean Air Act ("CAA") in 1970 with the goal of "foster[ing] the growth of a strong American economy and industry while improving human health and the environment." ${ }^{25}$ By 1990, the CAA is estimated to have "prevented more than 200,000 premature deaths, and almost 700,000 cases of chronic bronchitis." ${ }^{26}$ Then, after CAA revisions in 1990, the EPA was responsible for decreasing six criteria air pollutants (carbon monoxide, particulate matter, nitrogen oxides, sulfur dioxide, lead, and ozone) by forty-one percent, "while the Gross Domestic Product increased by more than 64 percent." ${ }^{27}$ The reduction of air pollution while simultaneously increasing GDP is proof that environmental and economic policies can coexist for the benefit of both sectors.

\section{B. Coal's Impact on Indiana}

Why are there so many coal-fired power plants in southwest Indiana? As just explained above, it's big coal country. Specifically, southwest Indiana is the only part of the state that has access to the Illinois Basin, one of the largest coal basins

21. Id.

22. Tristan, The History of Wood and Coal in Industrial Transport, BURYCOAL (Feb. 26, 2010), http://burycoal.com/blog/2010/02/26/the-history-of-wood-and-coal-in-industrial-transport/ [https://perma.cc/CZW8-JZCF].

23. Coal in the U.S. and Indiana, supra note 20.

24. Our Energy Sources, Fossil Fuels, Coal, NAT'L AcAds. ScI., ENG'G, Med., http://needtoknow.nas.edu/energy/energy-sources/fossil-fuels/coal/ [https://perma.cc/WP6E-7CH6].

25. 40th Anniversary of the Clean Air Act, U.S. Envtl. Prot. Agency (Sept. 14, 2010), https://www.epa.gov/clean-air-act-overview/40th-anniversary-clean-air-act [https://perma.cc/CS66WSUU].

26. $I d$.

27. Id. See Managing Air Quality, U.S. Envtl. Prot. Agency, https://www.epa.gov/airquality-management-process/managing-air-quality-air-pollutant-types [https://perma.cc/WFU47NPM]. 
in the US. ${ }^{28}$ In all, Indiana has roughly fifty-seven billion tons of unmined coal but only seventeen billion tons is accessible with current technology. ${ }^{29}$ Still, of the 17 billion tons of accessible coal, it is estimated to last Indiana up to 500 years. ${ }^{30}$ According to Indiana's Department of Natural Resources ("DNR"), Indiana produces up to thirty-five million tons of coal each year, consistently making it a top ten coal producing state in the country. ${ }^{31}$ Indiana's DNR contributed coal production to "ten southwestern Indiana counties" which results an additional $\$ 750+$ million to Indiana's economy. ${ }^{32}$ Indiana consumes approximately $75 \%$ of the 30 million tons of coal it produces each year (shipping the remaining to other states) and imports coal from West Virginia, Kentucky, Illinois, and Wyoming to meet remaining demands. ${ }^{33}$ Due to coals abundance and cheap source of energy, Indiana relies on it heavily. In $2018,70 \%$ of Indiana's electricity was generated by coal. ${ }^{34}$ Out of Indiana's 44,792 thousand short tons of coal consumption, 39,144 thousand short tons of it are used for electricity, making it the second largest-coal consumer in the country only behind Texas. ${ }^{35}$

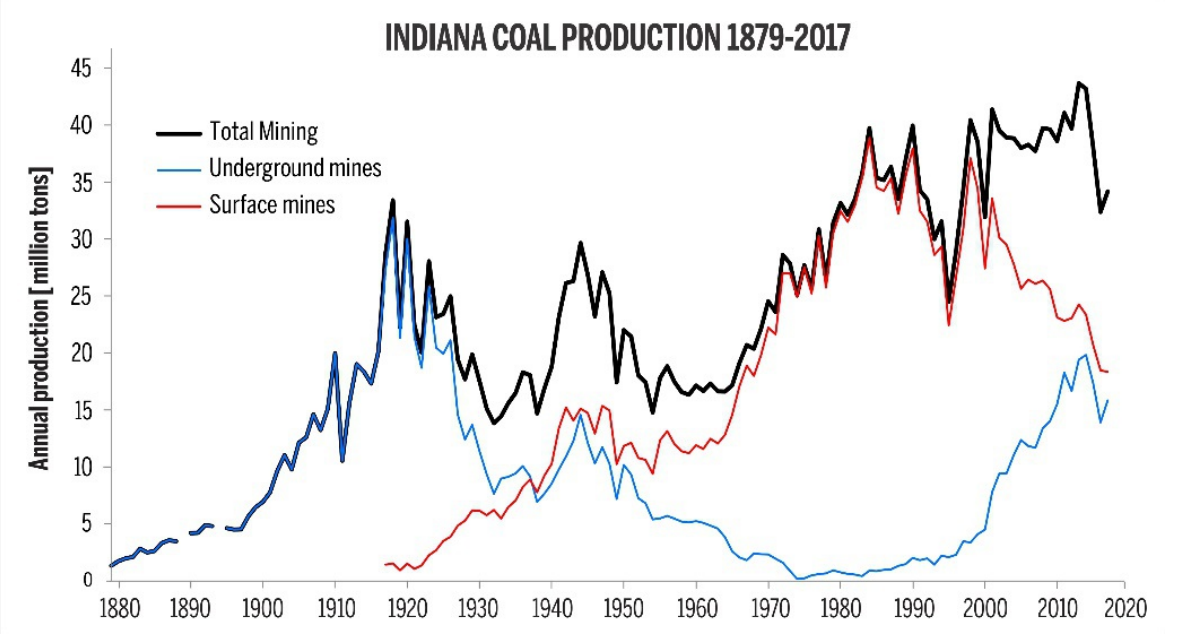

28. Indiana State Profile and Energy Estimates, U.S. ENERgY INFo. ADMIN., https://www.eia.gov/state/analysis.php?sid=IN [https://perma.cc/S3XZ-F4E9].

29. Coal in the U.S. and Indiana, supra note 20.

30. Id.

31. Indiana Coal by the Numbers, IND. DEP'T NAT. ResourCES, https://www.in.gov/ dnr/reclamation/3464.htm [https://perma.cc/Y9MC-NQDT].

32. Id.

33. Indiana State Profile and Energy Estimates, supra note 28.

34. Id.

35. Table F23: Coal Consumption Estimates and Imports and Exports of Coal Coke, 2018, U.S. ENERGY INFO. ADMIN., https://www.eia.gov/state/seds/sep_fuel/html/pdf/fuel_use_cl.pdf [https://perma.cc/B3E4-JDQ8]; id.

36. Coal in the U.S. and Indiana, supra note 20. 

ARE IMPACTING ITS CITIZENS

The amount of coal production and consumption therefore requires employment. The coal industry supplies up to 6,500 well-paying jobs in southwest Indiana. ${ }^{37}$ Further, because the cheap energy source provides an incentive for businesses, coal also relates to and is a cause for increased manufacturing jobs in Indiana. ${ }^{38}$ In 2013, manufacturing employed over 16\% (over 500,000 employees) of Indiana's workforce, the largest proportion for any state in the country. ${ }^{39}$

\section{POLLUTANTS PRODUCED BY COAL-FIRED POWER PLANTS AND THEIR CORRELATED HEALTH RISKS}

Air pollution caused by coal occurs when the chemical bonds holding carbon together are broken to release energy. ${ }^{40}$ Under the authority of the CAA, air pollutants have been characterized and grouped into two separate emission standards by the United States Environmental Protection Agency ("EPA"). ${ }^{41}$ The first group, known as "criteria air pollutants" consists of six specific pollutants, and includes particulate matter ("PM"), carbon monoxide ("CO"), lead ("Pb"), nitrogen dioxide (" $\mathrm{NO}_{2}$ ), ozone, and sulfur dioxide (" $\mathrm{SO}_{2}$,) which standards are controlled under the National Ambient Air Quality Standard ("NAAQS"). ${ }^{42}$ The second group includes a multitude of other "cancer causing" pollutants classified as Hazardous Air Pollutants ("HAPs") and are controlled under the National Emission Standards for Hazardous Air Pollutants ("NESHAPs"). ${ }^{43}$

\section{A. Criteria Air Pollutants}

Particulate matter ("PM") is a combination of solid particles and liquids found in the air and may contain a combination of up to "hundreds of difference chemicals. ${ }^{.44} \mathrm{PM}$ is categorized into two separate groups based on its size: $\mathrm{PM}_{10}$

37. See Economy at a Glance, BuREAU OF LABOR StATs., https://www.bls.gov/eag/eag. in.htm [https://perma.cc/C8B4-39K5].

38. See Mark Crawford, The States Leading the U.S. Manufacturing Resurgence, AREA DEVELOPMENT (Winter 2013), http://www.areadevelopment.com/RegionalReports/Q1-2013/statesleading-US-manufacturing-resurgence-2665542.shtml?Page=2 [https://perma.cc/7T24-VDY8].

39. Id.

40. Coal and Air Pollution, UniOn CONCERnEd SCIENTISTs (July 28, 2008, updated Dec. 19, 2017), https://www.ucsusa.org/resources/coal-and-air-pollution[https://perma.cc/EBR2-K98W].

41. Ind. Dep't Envtl. Management, E101 - Module One: Air Permitting 3 (2017), https://www.in.gov/idem/ctap/files/e101_air_manual.pdf [https://perma.cc/F4G3-GNUH].

42. Criteria Air Pollutants, U.S. Envtl. Prot. AgEnCy, https://www.epa.gov/criteria-airpollutants [https://perma.cc/64T7-Y4GQ].

43. Hazardous Air Pollutants, U.S. Envtl. Prot. Agency, https://www.epa.gov/haps [https://perma.cc/W436-MWGC].

44. Particulate Matter (PM) Basics, U.S. EnVtL. Prot. AgenCy, https://www.epa.gov/pmpollution/particulate-matter-pm-basics [https://perma.cc/BM7M-JHML]. 
and $\mathrm{PM}_{2.5}{ }^{45} \mathrm{PM}_{10}$ is generally ten micrometers across or smaller and can be inhaled; meanwhile $\mathrm{PM}_{2.5}$ is generally two and a half micrometers across and smaller (in comparison, a single strand of hair is about 70 micrometers across) ${ }^{46}$ Although both $\mathrm{PM}_{10}$ and $\mathrm{PM}_{2.5}$ can be inhaled and cause health problems, $\mathrm{PM}_{2.5}$ is considered more dangerous because its size allows it to lodge deeper into the lungs where it can remain stagnant for many years or enter the bloodstream. ${ }^{47}$ Therefore, long or short term exposure to both types of PM have been linked to "illnesses and deaths from heart or lung disease" especially for sensitive groups like the elderly, children and those with preconditions ${ }^{48}$ Specifically, people with heart or lung diseases may experience chest pain, palpitations, shortness of breath, asthma attacks, cardiac arrhythmias, or heart attacks, and are therefore "more likely to visit emergency rooms, be admitted to hospitals, or ... even die." 49 Further, chronic illnesses may develop, like: congestive heart failure, coronary artery disease, chronic obstructive pulmonary disease, severe asthma, and chronic bronchitis - leading to more medications and more doctor visits. ${ }^{50}$

Carbon monoxide ("CO") is a colorless, odorless gas released when "something is burned" and can be harmful in large amounts. ${ }^{51}$ The primary producers of $\mathrm{CO}$ are vehicles or machinery that burn fossil fuels. ${ }^{52} \mathrm{CO}$ causes health problems by entering the bloodstream and binding to hemoglobin (the component in blood that carries oxygen to cells) ${ }^{53}$ and reduces the amount of oxygen that can be transported to critical organs (i.e. the heart and brain). ${ }^{54}$ If inhaled in a confined space, $\mathrm{CO}$ can "cause dizziness, confusion, unconsciousness and death." ${ }^{55}$ Due to the concentration levels that CO needs to be harmful, it is unlikely for the health problems to persist while outside.$^{56}$ However, the effects of $\mathrm{CO}$ poisoning impact adults and children differently. The Journal of Toxicology conducted a two-year study where they found, in general, that adults with CO poisoning resulted in symptoms "like headache, nausea, and coma were less frequent, whereas loss of consciousness, convulsions, and lethargy were more

45. Id.

46. Id.

47. Health and Environmental Effects of Particulate Matter (PM), U.S. EnVTL. PROT. AGENCY, https://www.epa.gov/pm-pollution/health-and-environmental-effects-particulate-matterpm [https://perma.cc/TMB5-7NXS].

48. Craig N. Johnston et al., Legal Protection of the Environment 354-55 (4th ed. 2018).

49. Id.

50. Id.

51. Basic Information about Carbon Monoxide (CO) Outdoor Air Pollution, U.S. EnVtL. Prot. Agency, https://www.epa.gov/co-pollution/basic-information-about-carbon-monoxide-cooutdoor-air-pollution\#What\%20is\%20CO [https://perma.cc/P9UH-8UNV].

52. Id.

53. JOHNSTON ET AL., supra note 48, at 355.

54. Basic Information about Carbon Monoxide (CO) Outdoor Air Pollution, supra note 51.

55. Id.

56. $I d$. 
frequent in children than in adults." ${ }^{157}$ Further, the Journal of Toxicology found that the impacts of $\mathrm{CO}$ poisoning effected a fetus more prevalently than the mother and that "the severity of fetal intoxication cannot be assessed solely by the maternal state." ${ }^{58}$ Symptoms for a fetus include neurological dysfunction, decreased birth weight, and a four times more likelihood of fetal death. ${ }^{59}$

Lead $(\mathrm{Pb})$ is a natural metal that is emitted from coal-fired power plants. ${ }^{60}$ Once in the body, lead "distributes throughout the body in the blood and is accumulated in the bones." ${ }^{\prime 61}$ This accumulation can wreak havoc on the nervous system, immune system, cardiovascular system, kidneys, and reproductive and developmental systems. ${ }^{62}$ Further, like $\mathrm{CO}$, it can affect the "oxygen carrying capacity of the blood." ${ }^{63} \mathrm{~Pb}$ most commonly effects children neurologically, including behavioral problems, learning deficits, and lowered IQ (even in low amounts), and cardiovascular effects in adults. ${ }^{64}$

Nitrogen Dioxide $\left(\mathrm{NO}_{2}\right)$ is family to a group of highly reactive gases. ${ }^{65}$ It gets in the air primarily from burning fuels; therefore, automobiles and power plants are high producers. ${ }^{66} \mathrm{NO}_{2}$ primarily affects the respiratory system when inhaled. ${ }^{67}$ Short periods of exposure can aggravate already existing respiratory diseases and long exposures may contribute to the development of asthma and respiratory infection. ${ }^{68} \mathrm{NO}_{2}$ reacts with other particles in the air to form particulate matter and ozone. ${ }^{69}$ Further, it has been shown that children are again especially susceptible to excess levels of $\mathrm{NO}_{2}$, including "daily personal exposure to $\mathrm{NO}_{2}$ levels readily available in the domestic setting and chest tightness on the same day, breathlessness on exertion with a one-day lag, daytime and nighttime asthma attacks on the same day and with a one-day lag time."

Ozone is a gas that is composed of three atoms of oxygen and occurs in both the atmosphere and at ground level and can have positive or negative health affects depending on where it is found. ${ }^{71}$ Stratospheric ozone occurs naturally and

57. JOHNSTON ET AL., supra note 48, at 362.

58. $I d$.

59. Id.

60. See Union Concerned Scientists, supra note 40.

61. Id.

62. Id.

63. Id.

64. Id.

65. Basic Information about $\mathrm{NO}_{2}$, U.S. EnVtL. Prot. Agency, https://www.epa.gov/no2pollution/basic-information-about-no2\#What is NO2/ [https://perma.cc/G9AG-Y87W].

66. Id.

67. Id.

68. Id.

69. Id.

70. JOHNSTON ET AL., supra note 48, at 360.

71. Ground-Level Ozone Basics, U.S. EnVTL. Prot. AGENCY, https://www.epa.gov/groundlevel-ozone-pollution/ground-level-ozone-basics\#wwh [https://perma.cc/W4AS-GPCG]. 
is a protective layer against ultraviolet rays from the sun. ${ }^{72}$ However, ozone at the ground level has adverse effects against human health and is the primary proponent in smog. ${ }^{73}$ Ground level ozone is created by "chemical reactions between oxides of nitrogen $\left(\mathrm{NO}_{\mathrm{x}}\right)$ and volatile organic compounds (VOC). ${ }^{{ }^{74}} \mathrm{It}$ occurs when pollutants from vehicles and power plants chemically react in sunlight. ${ }^{75}$ Therefore, ozone reaches the most unhealthy levels on hot, sunny days, ${ }^{76}$ and it puts people who are active outdoors at the greatest risk because it penetrates deeper into the lungs during physical activity. ${ }^{77}$ Ozone can reduce lung function, making it more difficult to breathe deeply; when ozone levels are high, it causes an increased amount of asthma attacks that require medication or doctor visits; ozone can cause an "increase[d] susceptibility to respiratory infections;" and "[o]zone can inflame and damage the lining of the lungs" which, if repeatedly occurs, can result in permanent scarring of the lungs and therefore lower lung functionality and an overall lower quality of life. ${ }^{78}$

Sulfur dioxide $\left(\mathrm{SO}_{2}\right)$ is a toxic gas that is produced primarily from the "burning of fossil fuels by power plants . . ." Na9 Nasal passages naturally remove $\mathrm{SO}_{2}$, so moderate activity, or activity that triggers mouth breathing, is needed to trigger health effects. ${ }^{80}$ Exposure in small amounts affects the respiratory system, especially for children and people who suffer from asthma, ${ }^{81}$ and exposure specifically causes the "narrowing of the airways" which leads to "wheezing, chest tightness, and shortness of breath." ${ }^{.82}$ In larger amounts, the same symptoms can occur in healthy individuals. ${ }^{83}$ Larger amounts of $\mathrm{SO}_{2}$ emissions can also mix with other sulfur oxides in the air and contribute to creating PM. ${ }^{84}$ Finally, longterm exposure of $\mathrm{SO}_{2}$ "can cause respiratory illness, alter the lung's defense mechanisms, and aggravate existing cardiovascular disease." 85

\section{B. Hazardous Air Pollutants}

Hazardous Air Pollutants (HAPs) are pollutants that are known or expected to cause cancer or other serious health effects, including issues with the immune,

72. $I d$.

73. Id.

74. Id.

75. Id.

76. See JOHNSTON ET AL., supra note 48, at 358.

77. Id. at 353 .

78. Id. at 354 .

79. Sulfur Dioxide Basics, U.S. Envtl. Prot. Agency, https://www.epa.gov/so2pollution/sulfur-dioxide-basics\#what is so2 [https://perma.cc/L5X4-MGDC].

80. JohnStON ET AL., supra note 48, at 355.

81. Sulfur Dioxide Basics, supra note 79.

82. Johnston ET AL., supra note 48 , at 355.

83. Id.

84. Sulfur Dioxide Basics, supra note 79.

85. JOHNSTON ET AL., supra note 48, at 355. 
neurological, reproductive, developmental, and respiratory systems. ${ }^{86}$ HAPs most produced by power plants include metals like cadmium, mercury, and chromium. ${ }^{87}$

\section{FEDERAL AND STATE EMISSION STANDARDS}

\section{A. Federal Emission Compliance and Monitoring Standards for Stationary Facilities}

The authority for determining federal emission standards for coal-fired power plants falls under the EPA. This authority is delegated to the EPA from the Clean Air Act of 1990 (CAA) ${ }^{88}$ The CAA creates two broad areas of regulatory authority: (1) for "criteria air pollutants" like fine particulate matter, carbon monoxide, lead, sulfur dioxide and nitrogen dioxide through the National Ambient Air Quality Standard (NAAQS), and (2) for "hazardous air pollutants" (HAP) through the National Emission Standard for Hazardous Air Pollutants (NESHAPs).

\section{National Ambient Air Quality Standard}

\section{a. Process of reviewing the national ambient air quality standards}

The National Ambient Air Quality Standards (NAAQS) are contained under sections 108 and 109 of the CAA with its primary purpose being for the EPA to review and revise the science used to set standards for "criteria air pollutants." A review of the NAAQS is a comprehensive five step process which includes: Planning, an Integrated Science Assessment ("ISA"), Risk/Exposure Assessment ("REA"), Policy Assessment ("PA"), and Rulemaking. ${ }^{90}$ The planning phase begins with a "science policy workshop," that entails gathering input from the scientific community and the public "regarding policy-relevant issues and questions that will frame the review." "' Based from the input received, EPA prepares an "Integrated Review Plan" ("IRP") which outlines the schedule for the review, the process used to conduct the review, and the "policy-relevant science

86. Health and Environmental Effects of Hazardous Air Pollutants, U.S. ENVTL. Prot.

AGENCY, https://www.epa.gov/haps/health-and-environmental-effects-hazardous-air-pollutants [https://perma.cc/NAG3-J7LR].

87. See id. Coal and Air Pollution, supra note 40.

88. Controlling Hazardous Air Pollutants, U.S. EnVtl. Prot. AgEnCy, https://www.epa.gov/ haps/controlling-hazardous-air-pollutants [https://perma.cc/Q9EU-KD39].

89. See Criteria Air Pollutants, supra note 42.

90. Process of Reviewing the National Ambient Air Quality Standards, U.S. EnVtL. Prot. AGENCY, https://www.epa.gov/criteria-air-pollutants/process-reviewing-national-ambient-airquality-standards [https://perma.cc/4TSJ-JBHX].

91. Id. 
issues" that will be covered. ${ }^{92}$ Second, the ISA phase is a more comprehensive assessment of the "most policy-relevant science." 93 Third, the REA phase draws from the conclusions presented in the ISA and used to "develop quantitative characterizations of exposures and associated risks to human health" that are associated with current air quality conditions and with air quality that is estimated to meet the current or possible alternative standards, including any uncertainties about the estimates. ${ }^{94}$ Fourth, is the policy assessment phase, which provides an analysis of the "scientific basis for alternative policy options" under consideration by senior EPA management. ${ }^{95}$ This phase helps connect how the EPA decides whether to revise or retain current NAAQS standards based on the scientific evidence collected in the earlier phases and the recommendation from the Clean Air Scientific Advisory Committee ("CASAC"). ${ }^{96}$ The PA and CASAC focuses on evaluating the basic elements of the NAAQS, which includes: indicator, averaging time, form, and level. ${ }^{97}$ Finally, the rulemaking stage considers the information from all other stages and publishes a "notice of proposed rulemaking" that outlines the EPA's review of the NAAQS. ${ }^{98}$ Afterwards, a public comment period occurs, and a public hearing is usually held. ${ }^{99}$ The final rule is published once public comments are taken into consideration. ${ }^{100}$

\section{b. The national ambient air quality standard designation process}

The NAAQS designation process is implemented after a standard is created or revised to determine if areas of the country abide by them. ${ }^{101}$ The process begins by states submitting recommendations to the EPA on whether an area within their jurisdiction meets the new standards. ${ }^{102}$ A state's recommendation is based on monitors that collect air quality data and are located throughout the state. ${ }^{103}$ The EPA then compares this data against the new standard to determine if an area is in "attainment or nonattainment." ${ }^{104}$ An attainment area is a region that "meets or is cleaner than the [new] national standard" and no further step is necessary. ${ }^{105}$ A nonattainment area is a region that does not qualify under the new

92. Id.

93. Id.

94. Id.

95. Id.

96. Id.

97. Id.

98. Id.

99. Id.

100. Id.

101. NAAQS Designation Process, U.S. Envtl. Protection Agency, https://www.epa.gov/ criteria-air-pollutants/naaqs-designations-process [https://perma.cc/R7AX-6YEL].

102. Id.

103. Id.

104. Id.

105. Id. 
standard. ${ }^{106}$ Under either designation state and local governments must develop implementation plans outlining how areas will attain and maintain the standards by reducing air pollution emissions." 107

\section{c. The national ambient air quality standard state implementation plans}

Once the designation process is finished, states must develop general plans for all areas concerning how an area will seek or maintain attainment and specific plans on how an area designated nonattainment will reach attainment. These are known as State Implementation Plans (SIPs). ${ }^{108}$ SIPs are developed by state and local "air quality management agencies" and must be approved by the EPA. ${ }^{109}$ There are two purposes for SIPs: (1) they "[d]emonstrate that the state has the basic air quality management program components in place to implement a new or revised NAAQS" and (2) they "[i]dentify the emissions control requirements the state will rely upon to attain and/or maintain the primary and secondary NAAQS." ${ }^{110}$ The SIP development process begins with the designation of an area as achieving attainment or nonattainment. ${ }^{111}$ Within three years after new NAAQS are set, all states must submit a SIP proving that they have the appropriate components to implement the new standards. ${ }^{112}$ SIPs for nonattainment areas are due within eighteen to thirty-six months, with varying dates being based on the type of pollution and area classification. ${ }^{113}$ For example, due dates for sulfur dioxide $\left(\mathrm{SO}_{2}\right)$, nitrogen dioxide $\left(\mathrm{NO}_{2}\right)$, coarse particle pollution $\left(\mathrm{PM}_{10}\right)$, and lead $(\mathrm{Pb})$ are due no later than eighteen months after designation, and pollutants like Ozone $\left(\mathrm{O}_{3}\right)$, fine particle pollution $\left(\mathrm{PM}_{2.5}\right)$, and carbon monoxide $(\mathrm{CO})$ are generally given thirty-six months from designation. ${ }^{114}$ These nonattainment SIPs must outline "the strategies and emissions control measures that show how the area will improve air quality and meet the NAAQS." 115 Further, "SIPs must be developed with public input, be formally adopted by the state, and submitted by the Governor's designee to EPA."116 The EPA must then either approve or disapprove all or part of the plan after further consideration from the public and before its final action is enforced. ${ }^{117}$ If all or

106. Id.

107. Id.

108. NAAQS Implementation Process, U.S. EnVtL. Prot. AgENCY, https://www.epa.gov/ criteria-air-pollutants/naaqs-implementation-process [https://perma.cc/697K-PU5L].

109. Id.

110. $I d$.

111. $I d$.

112. Id.

113. $I d$.

114. Id.

115. Id.

116. Id.

117. Id. 
part of a SIP is approved, then it is enforceable in federal court, if a state does not pass the EPA's consideration, then the "EPA is required to develop a federal implementation plan (FIP)."118

\section{d. National ambient air quality standard for each criteria air pollutant}

The Clean Air Act identifies two separate national ambient air quality standards for criteria air pollutants: (1) the primary standard and (2) the secondary standard. ${ }^{119}$ The primary standard is designated for "public health protection including protecting the health of 'sensitive' populations such as asthmatics, children, and the elderly." 20 The secondary standard provides for "public welfare protection, including protection against decreased visibility and damage to animals, crops, vegetation, and buildings."121 Three separate units of measurements for criteria air pollutants are used and include "parts per million ( $\mathrm{ppm}$ ) by volume, parts per billion ( $\mathrm{ppb}$ ) by volume and micrograms per cubic meter of air $\left(\mu \mathrm{g} / \mathrm{m}^{3}\right){ }^{122}$ The following table is the EPA's current primary and secondary standard for each criteria air pollutant. ${ }^{123}$

\begin{tabular}{|l|l|l|l|l|}
\hline Pollutant & Primary/Secondary & $\begin{array}{l}\text { Average } \\
\text { Time }\end{array}$ & Level & Form \\
\hline $\begin{array}{l}\text { Carbon } \\
\text { Monoxide } \\
\text { (CO) }\end{array}$ & Primary & 8 hours & $9 \mathrm{ppm}$ & $\begin{array}{l}\text { Not to be } \\
\text { exceeded more } \\
\text { than once per } \\
\text { year }\end{array}$ \\
\cline { 2 - 5 } & $\begin{array}{l}\text { Lead (Pb) } \\
\text { Secondary }\end{array}$ & $\begin{array}{l}\text { Rolling 3- } \\
\text { month } \\
\text { average }\end{array}$ & $0.15 \mu \mathrm{g} / \mathrm{m}^{3}$ & $\begin{array}{l}\text { Not to be } \\
\text { exceeded }\end{array}$ \\
\hline $\begin{array}{l}\text { Nitrogen } \\
\text { Dioxide } \\
\left(\mathbf{N O} \mathbf{2}_{\mathbf{2}}\right)\end{array}$ & Primary & 1 hour & $100 \mathrm{ppb}$ & $\begin{array}{l}\text { 98th percentile } \\
\text { of 1-hour daily } \\
\text { maximum } \\
\text { concentrations } \\
\text { averaged over } \\
3 \text { years }\end{array}$ \\
\hline & $\begin{array}{l}\text { Primary and } \\
\text { Secondary }\end{array}$ & 1 year & $53 \mathrm{ppb}$ & Annual Mean \\
\hline
\end{tabular}

118. Id.

119. NAAQS Table, U.S. ENVTL. PROT. AGENCY, https://www.epa.gov/criteria-airpollutants/naaqs-table [https://perma.cc/MM2S-RG25].

120. Id.

121. Id.

122. Id.

123. Id. 
ARE IMPACTING ITS CITIZENS

\begin{tabular}{|c|c|c|c|c|}
\hline Ozone $\left(\mathrm{O}_{2}\right)$ & $\begin{array}{l}\text { Primary and } \\
\text { Secondary }\end{array}$ & 8 hours & $0.070 \mathrm{ppm}$ & $\begin{array}{l}\text { Annual fourth- } \\
\text { highest daily } \\
\text { maximum 8- } \\
\text { hour } \\
\text { concentration, } \\
\text { averaged over } \\
3 \text { years }\end{array}$ \\
\hline \multirow[t]{3}{*}{$\mathbf{P M}_{2.5}$} & Primary & 1 year & $12.0 \mu \mathrm{g} / \mathrm{m}^{3}$ & $\begin{array}{l}\text { annual mean, } \\
\text { averaged over } \\
3 \text { years }\end{array}$ \\
\hline & Secondary & 1 year & $15.0 \mu \mathrm{g} / \mathrm{m}^{3}$ & $\begin{array}{l}\text { annual mean, } \\
\text { averaged over } \\
3 \text { years }\end{array}$ \\
\hline & $\begin{array}{l}\text { Primary and } \\
\text { Secondary }\end{array}$ & 24 hours & $35 \mu \mathrm{g} / \mathrm{m}^{3}$ & $\begin{array}{l}\text { 98th percentile, } \\
\text { averaged over } \\
3 \text { years }\end{array}$ \\
\hline $\mathbf{P M}_{10}$ & $\begin{array}{l}\text { Primary and } \\
\text { Secondary }\end{array}$ & 24 hours & $150 \mu \mathrm{g} / \mathrm{m}^{3}$ & $\begin{array}{l}\text { Not to be } \\
\text { exceeded more } \\
\text { than once per } \\
\text { year on } \\
\text { average over } 3 \\
\text { years }\end{array}$ \\
\hline \multirow[t]{2}{*}{$\begin{array}{l}\text { Sulfur } \\
\text { Dioxide } \\
\left(\mathrm{SO}_{2}\right)\end{array}$} & Primary & 1 hour & $75 \mathrm{ppb}$ & $\begin{array}{l}\text { 99th percentile } \\
\text { of } 1 \text {-hour daily } \\
\text { maximum } \\
\text { concentrations, } \\
\text { averaged over } \\
3 \text { years }\end{array}$ \\
\hline & Secondary & 3 hours & $0.5 \mathrm{ppm}$ & $\begin{array}{l}\text { Not to be } \\
\text { exceeded more } \\
\text { than once per } \\
\text { year }\end{array}$ \\
\hline
\end{tabular}

\section{National Emission Standard for Hazardous Air Pollutants}

HAPs are pollutants that are known or expected to cause cancer or other serious health effects, like reproductive birth defects. ${ }^{124}$ HAPs originate from

124. National Emission Standards for Hazardous Air Pollutants Compliance Monitoring, U.S. Envtl. Protection Agency, https://www.epa.gov/compliance/national-emission-standards- 
man-made sources including mobile sources like vehicles, and stationary sources like power plants. ${ }^{125}$ NESHAP standards are set for stationary sources emitting HAPs and are conducted in two separate phases. ${ }^{126}$ Phase one is a "technologybased" standard where the EPA sets emission standards based from sources of an industry group. ${ }^{127}$ These standards are considered "maximum achievable control technology" (MACT) and are based on "emissions levels that are already being achieved by the controlled and low-emitting sources in an industry." 28 Phase two is based off "residual risks" where the EPA is required to assess the remaining health risks within eight years of setting the MACT standard and more stringent standards are necessary if the current standards do not "protect public health with an ample margin of safety." 129 The requirements for these regulations took effect between 1999 and 2011, the EPA projects that once the standards are fully implemented, they will reduce "annual air toxics emissions by about 1.7 million tons." $" 130$

Next, the EPA is mandated to conduct compliance monitoring inspections of facilities under NESHAP, which includes: "[r]eviewing reports and records, [i]nterviewing facility personnel knowledgeable of the facility, [i]nspecting the processes that have emissions points subject to the standard sampling wastewater discharges . . . , [i]nspecting against design and work practice standards, [and] [r] eviewing leak detection and repair methods."131 Facilities must then perform an "initial performance test to demonstrate compliance" and must monitor emissions based on parameters from the initial performance test to demonstrate continued compliance. ${ }^{132}$ If a facility meets the CAA's definition of a "major source" then a state or regional office is required to perform a "full compliance evaluation" once every two years. ${ }^{133}$ A full compliance evaluation is just that, a "comprehensive evaluation of the compliance status of the facility." 134 Specifically, it evaluates the regulated pollutants and emission units of the

hazardous-air-pollutants-compliance-monitoring [https://perma.cc/N6XG-M2N3].

125. Hazardous Air Pollutants: Sources and Exposure, U.S. Envtl. Protection Agency, https://www.epa.gov/haps/hazardous-air-pollutants-sources-and-exposure [https://perma.cc/ZVK8SL8L].

126. National Emission Standards for Hazardous Air Pollutants Compliance Monitoring, supra note 124.

127. Controlling Hazardous Air Pollutants, supra note 88.

128. Id.

129. Id.

130. Reducing Emissions of Hazardous Air Pollutants, U.S. EnVtl. Protection Agency, https://www.epa.gov/haps/reducing-emissions-hazardous-air-pollutants [https://perma.cc/34QDMQPQ].

131. National Emission Standards for Hazardous Air Pollutants Compliance Monitoring, supra note 124.

132. Id.

133. Id.

134. How We Monitor Compliance, U.S. Envtl. Prot. Agency, https://www.epa.gov/ compliance/how-we-monitor-compliance\#pane-5 [https://perma.cc/58DF-FDTP]. 
facility, as well as the facilities ability to maintain continued compliance. ${ }^{135}$

\section{B. Indiana's Monitoring, Designation, and Implementation}

Implementing effective air pollution controls would be too broad of a task for the EPA to do for each state; therefore, the Clean Air Act delegates some of the authority to the states. ${ }^{136}$ The CAA allows and even encourages states to implement their own rules that abide by the CAA so long as they meet the standards set by the EPA. ${ }^{137}$ However, states are not subjected to only meet the standards set by the EPA, the CAA allows states to implement - more restrictive standards - as long as they do not "void any part of the federal regulation." 138 The same is true for local governments as well. ${ }^{139}$ In Indiana, the state regulatory authority falls under the responsibility of the Indiana Department of Environmental Management (IDEM). ${ }^{140}$

\section{Indiana's Environmental Rules Board and Permits}

Indiana Code (IC) 13-13-8 permits IDEM to create the Environmental Rules Board (the "Board") which encompasses the broad task of adopting rules and regulations for all air pollution. ${ }^{141}$ The Board specifically establish requirements for issuing air permits, which includes: (1) "[p]ermits to control or limit the emission of any contaminants into the atmosphere;" (2) "[p]ermits for the construction, installation, or modification of facilities, equipment, or devises to control or limit any discharge, emission, or disposal of contaminants into the air;" and (3) [p]ermits for the operation of facilities, equipment, or devices to control or limit the discharge, emission, or disposal of any contaminants into the environment." ${ }^{142}$ In general, all sources that emit regulated air pollutants must apply for an air permit to do so. ${ }^{143}$ In order to receive a permit, applications submitted to IDEM must outline several factors, most important of which are

135. $I d$.

136. Delegation of Clean Air Act Authority, U.S. Envtl. Prot. Agency, https://www.epa. gov/caa-permitting/delegation-clean-air-act-authority [https://perma.cc/RKX3-9EV6].

137. Ind. DeP'T ENVTL. MGMt, supra note 41, at 3.

138. Id.

139. Id. at 3-4.

140. See Ind. Dep't Envtl. Mgmt., Air Quality, IN.gov, https://www.in.gov/idem/airquality/ [https://perma.cc/S8TV-CNCZ].

141. Ind. Dep't Envtl. Mgmt., Environmental Rules Board, IN.GOV , https://www.in.gov/idem/ legal/2348.htm [https://perma.cc/QG9Y-86KE].

142. Lucas D. Martin, 5 Ind. L. Encyc. Conserv. § 4 Permit Requirements, (Westlaw 2019) (database updated Jan. 2019).

143. Ind. Dep't Envtl. Mgmt., Air Permit Applications, IN.gov, https:/www.in.gov/idem/ airquality/2495.htm [https://perma.cc/D6EA-U8QW]. 
those used to calculate a source's potential to emit ("PTE"). ${ }^{144}$ IDEM calculates PTE by taking the maximum amount of air pollution that each piece of equipment may emit if it operates at full capacity, without any pollution control equipment for twenty-four hours a day, 365 days a year. ${ }^{145}$ PTE is then used to determine which air permit level the source will receive and the air pollution laws that will regulate it. ${ }^{146} \mathrm{~A}$ lower level permit will be issued directly to the source but higherlevel permits are subject to public comments and approval from the EPA. ${ }^{147}$

Air permits consists of five main sections. First, the Source Summary describes the type of industry the source pertains to and the equipment that will be regulated by the permit. ${ }^{148}$ The second section entails the general conditions that apply to all permitted sources. ${ }^{149}$ The third section includes the operating conditions that apply to all sources. ${ }^{150}$ The fourth entails the specific operating conditions for the source, including specific regulations and controls or limitations on emissions. ${ }^{151}$ Finally, the last section is an incorporation of federal standards. ${ }^{152}$

\section{Indiana's Air Quality Modeling Policies}

IDEM requires "air dispersion modeling" to demonstrate that a source will not violate air quality standards. ${ }^{153}$ Indiana models its air quality policies in three separate categories, each complying with EPA's standards: (1) Major Source Prevention of Significant Deterioration (PSD) modeling, (2) non-attainment New Source Review (NSR) modeling, and (3) Hazardous Air Pollutants (HAPs) emissions modeling. ${ }^{154}$

\section{a. Major source prevention of significant deterioration modeling}

"A source applying for a PSD permit or modification is required to perform modeling when its potential to emit (PTE) ... is over the thresholds used to

144. See Ind. Dep't Envtl. Mgmt., Terms and Definitions, IN.gov, https://www.in.gov/idem/ airquality/2532.htm [https://perma.cc/D4EY-5P5M].

145. Id.

146. See id.

147. See Ind. Dep't Envtl. Mgmt., Air Permitting Timeframes and Fees, IN.GOv, https://www. in.gov/idem/airquality/2648.htm [https://perma.cc/F3CY-66UL].

148. Ind. Dep't Envtl. Mgmt., Air Permitting Background and Terminology, IN.gov, https:/www.in.gov/idem/airquality/2649.htm [https://perma.cc/7ZSK-VJCX].

149. Id.

150. See id.

151. Id.

152. Id.

153. Ind. Dep't Envtl. Mgmt., Modeling, IN.GOv, https://www.in.gov/idem/airquality/ 2375.htm [https://perma.cc/EG6Q-3F29].

154. Ind. Dep't Envtl. Mgmt., Air Quality Modeling Policies 5 (2018), https://www.in. gov/idem/airquality/files/modeling_policies.pdf [https://perma.cc/VN42-Z382]. 
determine PSD applicability." 155 Depending on the source category, new sources must emit a PTE greater than 100 or 250 tons per year to require PSD modeling. ${ }^{156}$ For an already existing major source, any modification pertaining to a criteria air pollutant must exceed the "significant emission rate" distinguished in 326 IAC 2-2-1 to make it a major modification. ${ }^{157}$ Measurements are calculated in tons per year and include:

- Carbon Monoxide-100

- Nitrogen Oxides-40

- Sulfur Dioxide - 40

- Fine Particulate Matter-10

- Coarse Particulate Matter-15

- Ozone- $40^{158}$

Next, IDEM determines the "significant impact level" of the new or modified source determined by the "significant net emissions increase" from the source. ${ }^{159}$ "Once the significant net increase is determined, the proposed project is modeled to determine if it is above the [significant impact level]." 160 "If the project does not exceed the significant impact levels" of any pollutant then "no further modeling is required." 161 If, however, the project does exceed significant impact levels then the "modeling impact analysis" must include: "the potential emissions after controls from the proposed new source or emissions from the existing source including the potential emissions from the proposed modification after controls; all other sources inside the [significant impact area]; and other distant sources taken from the NAAQS inventory that may impact this [significant impact area]." ${ }^{, 162}$

HAP analysis modeling is required for a source to retain a permit, but it further provides information to the public about the HAPs emission health impact on the area. ${ }^{163}$ Modeling is based on major sources and major sources are considered any source that has a potential to emit any single HAP by an excess of ten tons per year, or all HAPs combined by twenty-five tons per year. ${ }^{164}$ For modifications that exceed these standards, IDEM uses an approved EPA dispersion model to "calculate off-site HAPs . . concentrations in conjunction with toxicological information to conduct a cancer risk and hazard screening evaluation."165

155. Id.

156. Id. at 7 .

157. Id.

158. Id.

159. Id at 11 .

160. Id.

161. Id.

162. Id.

163. Id at 39 .

164. Id. at 38 .

165. Id at 39 . 
IDEM also calculates the potential risk of cancer to the area's inhabitants from the HAPs emissions. ${ }^{166}$ It does this by "multiplying the maximum, modeled annual concentration by its corresponding Unit Risk Factor for carcinogenic HAPs" to estimate potential cancer risk for a single individual (i.e. Cancer Risk $=$ Annual Concentration $\mathrm{x}$ Unit Risk Factor). ${ }^{167}$ The result represents an "estimated individual cancer risk" based on the probability that a single person may develop cancer over the course of their lifetime due to exposure to the HAP. ${ }^{168}$ It assumes that the individual has constant exposure to the HAP throughout his life (24 hours a day, 365 days a year, for 70 years) ${ }^{169}$ IDEM considers any value above $1 \times 10^{-6}$ to be a "level of concern" and will conduct another, more refined analysis. ${ }^{170}$ The "upper range of acceptability" by the EPA is one in ten thousand (1.0E-04) cancer risks. ${ }^{171}$

\section{INDIANA SHOULD IMPLEMENT MORE STRINGENT AIR POLLUTION REGULATIONS}

For the amount of pollution being emitted by coal-fired power plants in southwest Indiana, there has been very little nonattainment issues overall. ${ }^{172} \mathrm{In}$ fact, Indiana has repeatedly met attainment standards that have only increased since the CAA was enacted. ${ }^{173}$ Since 2005, out of nine southwest counties (including Daviess, Dubois, Gibson, Knox, Pike, Posey, Spencer, Vanderburgh, and Warrick) seven counties have been in nonattainment for a pollutant, and only Pike, Vanderburgh, and Warrick counties being in nonattainment for multiple pollutants. ${ }^{174}$ As of 2019 only two counties, Daviess and Pike, are in nonattainment, with both exceeding $\mathrm{SO}_{2}$ levels. ${ }^{175}$ However, as is permissible under the CAA, Indiana has not adopted regulations that are more stringent than EPA's standards. ${ }^{176}$ Due to the current nonattainment standards being a relative non-issue and the fact that Indiana's citizens still incur adverse health effects from air pollution, Indiana should adopt regulations that impose stricter emission

\footnotetext{
166. Id. at 40 .

167. Id.

168. Id.

169. Id.

170. Id.

171. Id.

172. See Ind. Dep't Envtl. Mgmt., Current and Historical List of Nonattainment AREAS BY COUNTY, https://www.in.gov/idem/airquality/files/nonattainment_county_list.pdf [https://perma.cc/HJD6-4XTK].

173. See id.

174. Ind. Nonattainment/Maintenance Status for Each County by Year for All Criteria Pollutants, U.S. ENVTL. PROT. AGENCY, https://www3.epa.gov/airquality/greenbook/anayo_in.html [https://perma.cc/2ZZZ-6DGN].

175. Id.

176. See Ind. Dep't Envtl. Mgmt., Nonattainment Status for Ind. Counties, IN.gov, https://www.in.gov/idem/airquality/2339.htm [https://perma.cc/UT9L-L86R].
} 
standards.

\section{A. Indiana Compared to States with more Stringent Regulations}

\section{California}

California is one of the most well-known states that has enacted stricter emission standards than the EPA. It did this through the development of the California Air Resources Board ("CARB"). CARB consists of sixteen members that represent various components of air pollution regulation. ${ }^{177} \mathrm{CARB}$ regulates air quality as part of a three-tiered approach: (1) the EPA setting national emission standards, (2) CARB setting the state's own stricter standards, and (3) thirty-five "local air pollution control districts regulat[ing] emissions from business and stationary facilities." ${ }^{\prime 178}$ CARB sets California's emission standards based on multiple factors including: (1) levels that "protect those at greatest risk," (2) "identifying pollutants that pose the greatest health risks," (3) measuring progress, (4) determining solutions based on "the best available science and technology," and (5) studying the "costs and benefits of pollution controls." Further, CARB considers public participation by holding monthly public meetings and by consulting with industry, scientific, and health experts. ${ }^{180}$ CARB's standards, known as CAAQS, are for the same six criteria air pollutants as the NAAQS, including four additional ones (which will not be discussed), and are as follows (with the EPA's and Indiana's in parenthesis):

CO:

- 8 hours - 9 ppm (IN 9 ppm)

- 1 hour-20 ppm (IN 35 ppm)

$\mathrm{Pb}:$

- 30-day average $-1.5 \mu \mathrm{g} / \mathrm{m}^{3}$ (IN on a rolling three-month average at 0.15 $\left.\mu \mathrm{g} / \mathrm{m}^{3}\right)$

$\mathrm{NO}_{2}$ :

- 1-hour-0.18 ppm (IN $100 \mathrm{ppb})$

- Annual-0.030 ppm (IN 0.053 ppm)

177. The California Air Resources Board, CAL. AIR Resources BOARD, https://ww2.arb.ca. gov/about [https://perma.cc/CN62-DMGF] (members consists of five who serve on local air districts, four experts in fields that shape air quality rules, two public members, two members who represent environmental justice communities, two nonvoting members appointed for legislative oversight, and one fulltime member that serves as the Chair).

178. Id.

179. Id.

180. Id. 


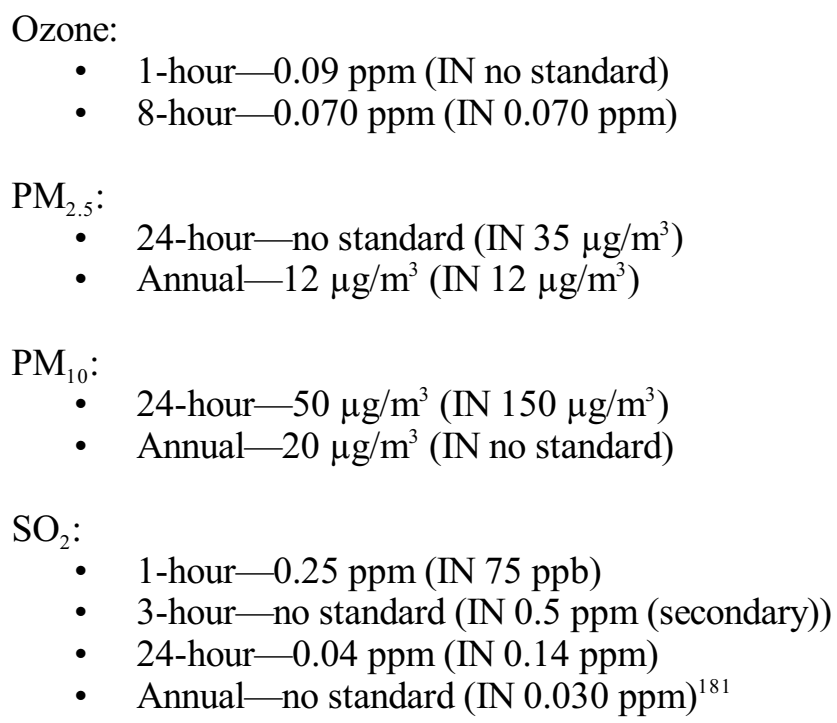

Still, CARB estimates that over " 90 percent of Californians breathe unhealthy levels of one or more air pollutants during some part of the year." ${ }^{182}$ Unlike Indiana though, coal was never a huge factor for energy consumption in California. ${ }^{183}$ However, stricter emission standards have caused coal to drop even lower than its already low level. ${ }^{184}$ For example, in 2007, the "total megawatt hours" attributed to coal was at a mere one percent, by 2015 it dropped even further to two-tenths of one percent. ${ }^{185}$ Secondly, the electric power consumption by coal dropped by ninety-six percent within those same years. ${ }^{186}$ Besides the CAAQS, other determining factors for decreasing coal use includes lower natural gas prices and California's overall goal for promoting renewable energy. ${ }^{187}$ Therefore, this correlation shows that if Indiana would adopt stricter emission standards, then utility companies would likely transition to alternate energy source.

181. Ambient Air Quality Standards, CAL. Air Resources BoArd (May 4, 2016), https://www.arb.ca.gov/research/aaqs/aaqs2.pdf?_ga=2.134284849.1327462312.15504445891717364413.1536618703 [https://perma.cc/3ZCQ-YCN9]. Nonattainment Status for Ind. Counties, supra note 176.

182. Common Air Pollutants, CAL. AIR ResourCes BOARD, https://ww2.arb.ca.gov/resources/ common-air-pollutants [https://perma.cc/RJ29-HW6W].

183. See Rob Nikolewski, California's coal collapse, SAN DiEgo Union-Trib. (May 5, 2016), https://www.sandiegouniontribune.com/sdut-california-coal-collapse-2016may05-story.html [https://perma.cc/5M5W-4YSX].

184. Id.

185. Id.

186. Id.

187. Id. 


\section{North Carolina}

Unlike California, and more similar to Indiana, North Carolina has relied on coal and manufacturing to develop its society and boost its economy. ${ }^{188}$ However, due to increasing pollution issues by outdated power plants, in 2002 North Carolina enacted the Clean Smokestacks Act (CSA), which is a regulation that specifically targeted a reduction in emissions of $\mathrm{NO}_{2}$ and $\mathrm{SO}_{2}$ from coal-fired power plants. ${ }^{189}$ The CSA established a maximum annual amount of emissions that coal-fired power plants could emit for those two pollutants; specifically, when compared to 1998 emission levels, requiring a "permanent" reduction of $77 \%$ in $\mathrm{NO}_{2}$ by 2009 , and $73 \%$ of $\mathrm{SO}_{2}$ by $2013 .{ }^{190}$ The goal of these emission standards were to either require the "modernization or retirement of all forty-five coal-fired generating units . . . at their fourteen sites in North Carolina." CSA was successful in achieving its primary objectives, by $2012 \mathrm{NO}_{2}$ emissions were reduced by $84 \%$ and $\mathrm{SO}_{2}$ emissions by $89 \% .{ }^{192}$ It forced Duke Energy-one of the super polluting utility companies in Indiana - to "retire[] or schedule[] retirement of fifteen of its twenty-eight coal-fired power plants" and it modernized the emission process for the rest. ${ }^{193}$

Studies have been conducted over the health and economic effectiveness of North Carolina's CSA. The International Journal of Environmental Science and Technology conducted one such study based on the health impact that CSA had on North Carolina's residents from 2002-2012. ${ }^{194}$ The study did so by comparing "observed $\mathrm{PM}_{2.5}$ sulfate concentrations to $\mathrm{SO}_{2}$ emissions over time and examin[ing] changes in the public health burden due to coal-fired power plant emissions . . ." "195 This study reinforces the data by confirming that $\mathrm{SO}_{2}$ emissions were reduced drastically by 2012 , stating that the "annual power plant $\mathrm{SO}_{2}$ emissions decreased from 459.7 thousand tons to 53.5 thousand tons." ${ }^{.196}$ It further found that the emission rate for North Carolina's piedmont region (the region that holds most of the state's coal-fired power plants), comparable to

188. See The Coal Institute, COAL InST., http://thecoalinstitute.org/ [https://perma.cc/2SG2WUZ4].

189. Richard N. L. Andrews, State Environmental Policy Innovations: North Carolina's Clean Smokestacks Act, 43 ENVTL. L. Rev. SYNDiCATE 881, 883 (2013), https:/law.lclark.edu/live/files/ 16063-43-4andrews [https://perma.cc/VG6S-8FKK].

190. $I d$.

191. Id.

192. Id.

193. Id.

194. Ya-Ru Li \& Jacqueline MacDonald Gibson, Health and Air Quality Benefits of Policies to Reduce Coal-Fired Power Plant Emissions: A Case Study in North Carolina, 48 EnVtL. SCI. \& TECH. 10019 (2014).

195. Id. at $10020\left(\mathrm{PM}_{2.5}\right.$ sulfate concentrations is a "major component" of $\mathrm{PM}_{2.5}$ found to be mainly emitted from coal-fired power plants).

196. Id. at 10022 . 
southwest Indiana, decreased at a significantly faster rate than the rest of North Carolina and that overall, North Carolina's emissions decreased significantly faster than surrounding states that had not adopted more stringent emission standards. ${ }^{197}$ Finally, a reduction in $\mathrm{SO}_{2}$ also correlated to a reduction in $\mathrm{PM}_{2.5}$ sulfate concentrations and again the greatest area of impact was North Carolina's piedmont region. ${ }^{198}$ From 2002-2012, $\mathrm{PM}_{2.5}$ sulfate concentration decreased from $4.2 \mu \mathrm{g} / \mathrm{m}^{3}$ to $1.7 \mu \mathrm{g} / \mathrm{m}^{3}$ which is a decrease of sixty percent. ${ }^{199}$ The study suggests that the reduction of $\mathrm{SO}_{2}$ and $\mathrm{PM}_{2.5}$ sulfate concentration is attributable to a reduction of premature deaths in North Carolina over the same period. ${ }^{200}$ Specifically, "all-cause deaths" from $\mathrm{PM}_{2.5}$ sulfate decreased by $63 \%$ from 2002 2012 and resulted in the prevention of 1,700 premature deaths - or, if " $\mathrm{PM}_{2.5}$ sulfate [emissions] had remained the same in 2012 as in 2002, then an additional 1700 deaths would have been expected."201

Overall, this study argues that the CSA has had multiple significant findings and benefits. ${ }^{202}$ Besides preventing 1700 premature deaths in North Carolina, the empirical data shows (as could be reasonably hypothesized) that the CSA reduced coal-fired power plant emissions quicker and more effectively than what federal implementation could have done alone - in other words, more stringent emission standards equals a greater reduction in that pollutant. ${ }^{203}$ The study supports this conclusion by comparing the rate of reduction between North Carolina and its neighboring states, which did not adopt stricter emission policies-finding that the average rate of reduction for southeastern states fell at about $13.6 \%$ annually, while North Carolina's reduction reached $20.3 \%$ annually. ${ }^{204}$ Next, the study argues that the CSA possibly did not only benefit North Carolina, but it also benefited surrounding states. ${ }^{205}$ It is estimated that the average distance that $\mathrm{SO}_{2}$ travels in the southeast is anywhere from 115 to 220 kilometers. ${ }^{206}$ A reduction of $\mathrm{SO}_{2}$ emissions traveling through the air has been shown to cause a reduction in $\mathrm{PM}_{2.5}$ sulfates as well, this is especially relevant when paired with the study's analysis that "direct reductions from local sources appear to be effective in reducing $\mathrm{PM}_{2.5}$ sulfate levels both locally and in surrounding areas."207

Another study also found similar health results when they analyzed the CSA. The International Journal of COPD "analyzed the trends of emphysema, asthma, and pneumonia mortality and changes of the levels of ozone, sulfur dioxide $\left(\mathrm{SO}_{2}\right)$, nitrogen dioxide $\left(\mathrm{NO}_{2}\right)$, carbon monoxide $(\mathrm{CO})$, and particulate matter

197. Id.

198. Id.

199. Id.

200. Id. at 10024 .

201. Id.

202. See id. at 10025.

203. Id.

204. Id.

205. Id.

206. Id.

207. Id. at $10022,10025$. 
$\left(\mathrm{PM}_{2.5}\right.$ and $\left.\mathrm{PM}_{10}\right) \ldots .{ }^{208}$ This study found that lower levels of $\mathrm{SO}_{2}, \mathrm{CO}$, and $\mathrm{PM}_{10}$ resulted in a decline in emphysema, asthma, and pneumonia deaths. ${ }^{209}$ It further concluded that improved air quality by decreasing levels of $\mathrm{SO}_{2}, \mathrm{CO}$, and $\mathrm{PM}_{10}$ in the air "contributed to the improved respiratory health of the North Carolina population." 210

However, the CSA was not only beneficial for North Carolina's public health, but it also created solutions to potential problems in the energy sector too. Utilities tend to favor "regulatory certainty" when it comes to compliance because plans, permits, construction and operating lifetimes tend to span over a period of decades for a facility. ${ }^{211}$ However, because of frequent policy changes at the federal level and actions by the courts "often creates unpredictable and short compliance timelines for environmental regulation." ${ }^{212}$ Therefore, since the CSA was enacted before federally mandated emission standards like the Cross-State Air Pollution Rule (CSAPR) and the Mercury Air Toxics Standard (MATS), the CSA created four benefits for utility companies and consumers. ${ }^{213}$ First, by the time that federally mandated emission standards are increased, utility companies are already in compliance with the new standards; which reduces the need for a sudden upgrade in emission technology. ${ }^{214}$ This becomes more important through the second benefit, which the study argues, that because the CSA was enacted before new federal emission standards, it created a longer compliance period; therefore, utility companies had more time to adjust to the new standards and could spread out consumer costs over a greater period of time. ${ }^{215}$ The third benefit distinguished by the study, again discusses the health benefits of reduced emissions, specifically stating that the health benefits are "an order of magnitude greater than potential increases in costs for ratepayers that may result from Clean Smokestacks. ${ }^{216}$ Finally, the CSA "likely reduced other environmental compliance costs" ${ }^{217}$ by avoiding compliance costs associated with NAAQS. ${ }^{218}$ The study concludes that it is possible (however, difficult) for a state to adopt

208. Julia Kravchenko et al., Long-term dynamics of death rates of emphysema, asthma, and pneumonia and improving air quality, 9 InT'L J. Chronic Obstructive Pulmonary Disease 613, 613 (2014).

209. Id.

210. Id. at 623 .

211. David Hoppock et al., Benefits of Early State Action in Environmental Regulation of Electric Utilities: North Carolina's Clean Smokestacks Act 1-25, 24 (Nicholas Inst. for Envtl. Policy Sols., Working Paper No. 12-05, 2012).

212. Id.

213. Id. at 3.

214. Id.

215. Id.

216. Id.

217. Id.

218. Id. at 25 . 
policies that benefit both utilities and environmental objectives. ${ }^{219}$ To do so, a state must incorporate "[c]ollaborative thinking about future risks and interdependencies between state utility policy, environmental quality, and state energy policy goals" in order to avoid inconsistencies within the energy sector while also improving the "quality of life for state citizens."

\section{B. Health Statistics}

The primary health conditions related to coal-fired power plant emissions include heart disease, lung disease, and cancer. ${ }^{221}$ This section will first discuss and compare Indiana health statistics compared to California and North Carolina. Secondly, it will compare Evansville to Fort Wayne, Indiana.

\section{Indiana's Health Compared California and North Carolina}

The three main causes of death in Indiana include heart disease, cancer, and chronic lower respiratory disease. ${ }^{22}$ According to the American College of Cardiology (College), air pollution can trigger a heart attack or stroke by reducing the heart's ability to pump blood. ${ }^{223}$ PM contributes the highest risk to triggering a cardiovascular event. ${ }^{224}$ The College recommends exercise to lower one's risk, however, it cautions doing so while in urban settings with high levels of traffic or in industrial areas. ${ }^{225}$

The Centers for Disease Control and Preventions (Center) keeps statistics for health-related deaths in all states and includes an age-adjusted rate for population comparison. ${ }^{226}$ According to the Center, heart disease was the leading cause of death for Indiana residents in 2016 at 13,952 deaths. ${ }^{227}$ This puts Indiana at an adjusted rate of 180.6, which is ranked as the thirteenth most in the US, and 15.1 points higher than the US average of $165.5 .^{228}$ In comparison, California had 61,573 heart disease related deaths in 2016, at an adjusted rate of 143.1, ranking it fortieth in the country. ${ }^{229}$ Further, North Carolina had 18,266 heart disease

219. $I d$.

220. Id.

221. Power Plants, U.S. NAT'L LiB. Med., (May 31, 2017) https://toxtown.nlm.nih.gov/ sources-of-exposure/power-plants [https://perma.cc/JWT9-8WJ6].

222. Stats of the State of Indiana, Ctrs. FOR Disease Control \& Prevention, https://www.cdc.gov/nchs/pressroom/states/indiana/indiana.htm [https://perma.cc/5GPW-HJSM].

223. Envtl. Prot. Agency, Heart Disease, Stroke, and Outdoor Air Pollution, https:www3.epa.gov/airnow/heartflyer.pdf [https://perma.cc/3HFV-X9KH].

224. Id.

225. Id.

226. See Stats of the State of Indiana, supra note 222.

227. Id.

228. $I d$.

229. Stats of the State of California, Ctrs. for Disease Control \& Prevention, https://www.cdc.gov/nchs/pressroom/states/california/california.htm [https://perma.cc/M2S5- 
related deaths, with an adjusted rating of 155.8, ranking it twenty-eighth in the country. ${ }^{230}$

Just under heart disease, follows cancer, which accumulated 13,424 deaths for Indiana in 2016. ${ }^{231}$ This corresponds to an adjusted rate of 172.5, ranked ninth in the US and 16.7 points above the country's average of $155.8 .^{232}$ Cancer is also the second highest leading cause of death in California in 2016, at 59,515 deaths its adjusted rate falls at 139.7 and ranked forty-fifth in the country. ${ }^{233}$ Cancer was the leading cause of death in North Carolina in 2016, taking 19,523 lives, its adjusted rate falls at 161.6 and corresponds to the nineteenth highest rating in the country. ${ }^{234}$

Finally, chronic lower respiratory disease took 4,214 Indiana lives in 2016 with an adjusted rate of 54.6, ranking it ninth in the country and above the countries average of 40.6 by 14 points. ${ }^{235}$ Chronic lower respiratory disease was California's fifth leading cause of death at 13,710 deaths in 2016, adjusted to 32.6 points it is ranked forty-third in the country. ${ }^{236}$ Finally, North Carolina lost 5,311 lives to chronic lower respiratory disease, with an adjusted rate of 44.8 and ranking it twenty-second in the country. ${ }^{237}$

\section{Vanderburgh County v. Allen County}

This subsection will compare Indiana's Vanderburgh County (Evansville) to Allen County which is located in the northeast corner of the state and holds Indiana's second largest city, Fort Wayne. ${ }^{238}$ Health comparisons are based off of Indiana INdicators, an interactive website that allows users to compare health statistics between specific counties in Indiana, with the data being updated with the most recent information. ${ }^{239}$ Although other factors contribute to the public health of an area, this data shows that Vanderburgh County, while being stuck

BFJC].

230. Stats of the State of North Carolina, Ctrs. for Disease Control \& Prevention, https://www.cdc.gov/nchs/pressroom/states/northcarolina/northcarolina.htm [https://perma.cc/R7WM-7MRY].

231. Stats of the State of Indiana, supra note 222

232. Id.

233. Stats of the State of California, supra note 229.

234. Stats of the State of North Carolina, supra note 230.

235. Stats of the State of Indiana, supra note 222.

236. Stats of the State of California, supra note 229.

237. Stats of the State of North Carolina, supra note 230.

238. Indiana, STATsINDiANA, http://www.stats.indiana.edu/profiles/profiles.asp?scope choice $=$ a\&county_changer $=18000[\mathrm{https}: / /$ perma.cc/8TD4-ANXU] (showing that Fort Wayne has a population of approximately 268,000 while Evansville is ranked Indiana's third largest city with a population of about 118,000$)$.

239. Health Maps, INDICATORS, http://indianaindicators.org/dash/map.aspx [https://perma.cc/ L4F3-6Y9W]. 
between four super polluters, ${ }^{240}$ is overall less healthy than Allen County which boasts a larger population and therefore a higher number of mobile sources. To continue the health-based risks most common with air pollution, comparisons will be drawn from cases of asthma, chronic lower respiratory disease, heart disease and cancer.

To begin, the data showed asthma emergency room (ER) visits for adults per a 10,000-population basis and found that Vanderburgh County recorded 68.8 cases while Allen County recorded 50.6. ${ }^{241}$ This number increased for children (ages five to seventeen) where Vanderburgh County recorded 88.8 cases while Allen County recorded 54.9 cases. ${ }^{242}$ Inversely, Allen County recorded a higher ratio of asthma hospitalizations for adults at 12.5 cases and 7.3 cases for children while Vanderburgh County recorded 10.7 cases for adults ${ }^{243}$ and 6.3 for children. ${ }^{244}$ Next, is chronic lower respiratory disease deaths per a 100,000 population basis and found that Allen County recorded 41.9 cases while Vanderburgh County recorded 77.3 cases. ${ }^{245}$ Vanderburgh County is also higher for heart disease cases recording 107.3 heart disease hospitalizations per 10,000 population while Allen County recorded 81.9 cases; ${ }^{246}$ and for heart disease deaths where Vanderburgh County recorded slightly more at 171.2 cases per 100,000 population basis while Allen County recorded 170 cases. ${ }^{247}$ Further, cancer deaths were also higher in Vanderburgh County, which recorded 194 deaths per 100,000 population basis, while Allen County recorded 172.2 deaths ${ }^{248}$ Finally, Vanderburgh County also recorded higher rates of new cancer cases per 100,000 population basis, 475.1 to $424.6,{ }^{249}$ new lung cancer cases, 79.2 to $61.7,{ }^{250}$ and lung cancer deaths, 56.9 to $46.8 .{ }^{251}$ The data also shows that adults in Vanderburgh County report a higher percentage of "poor to fair health" at $20.0 \%$ while Allen County adults reported in at $15.0 \%{ }^{252}$ This also correlates to the rate of premature deaths (ages 75 and below) in each county with Vanderburgh reporting 439 deaths and Allen County reporting 385 deaths. ${ }^{253}$ However, as mentioned above, these results could be impacted by other factors. For example, adults in Vanderburgh County reported a higher percentage of adults that lacked physical activity at $27 \%$ while Allen County reported $22 \%$ of

240. Hopkins, supra note 2.

241. Health Maps, supra note 239, at Asthma Emergency Dep't Visits Per 10k.

242. Id. at Child Asthma Emergency Dep't Visits Per 10k.

243. Id. at Asthma Hospitalizations Per 10k.

244. Id. at Child Asthma Hospitalizations Per 10k.

245. Id. at Chronic Lower Respiratory Disease Deaths Per 100k.

246. Id. at Heart Disease Hospitalizations Per 10k.

247. Id. at Heart Disease Deaths Per 100k.

248. Id. at Cancer Deaths Per 100k.

249. Id. at New Cancer Cases Per 100k.

250. Id. at New Lung Cancer Cases Per 100k.

251. Id. at Lung Cancer Deaths Per 100k.

252. Id. at Adults Reporting Poor to Fair Health.

253. Id. at Premature Deaths (Aged 75 and Under) Per 100k. 
adults. ${ }^{254}$ Further, the rate of adults who reported to smoke was also higher in Vanderburgh County at $21 \%$, with Allen County reporting $20 \%$ of its adults as smokers. ${ }^{255}$ Although, these factors contribute to public health, they do not rule out the fact that millions of tons of toxic pollutants by coal-fired power plants also impacts public health. ${ }^{256}$

\section{CONCLUSION}

Although coal has been a reliable and cheap resource, the public health benefits of implementing more stringent air pollution emission standards outweigh its economic benefit. Proof of this can be seen by comparing Indiana's health statistics with other states who have implemented more stringent standards, like California and North Carolina, and by comparing Indiana to national averages. Moreover, it is especially beneficial to look at the impact of North Carolina's Clean Smokestacks Act. North Carolina is similar to Indiana, in that it hosts a multitude of coal-fired power plants. ${ }^{257}$ Through the CSA, North Carolina was able to lower emission levels which benefited public health by forcing the shutdown of old coal-fired power plants. ${ }^{258}$ The CSA has been contributed to saving up to 1700 premature deaths alone. ${ }^{259}$ The CSA has also been argued to have benefited North Carolina economically by granting longer compliance periods for utilities to make adjustments and to also spread out any increased compliance costs to its customers over a longer period of time. ${ }^{260}$ This same theory could also be used to argue for a transition to renewable energy and leaving coal behind for good.

Besides the positive public health and environmental impacts from renewable energy sources, like solar and wind power, renewable energy sources produce jobs. Unlike fossil fuel jobs, "which are typically mechanized and capital intensive," renewable energy jobs are more labor intensive. ${ }^{261}$ Which means, that, "on average, more jobs are created for each unit of electricity generated from renewable sources than from fossil fuels." ${ }^{262}$ In 2016, wind energy employed over 100,000 full-time jobs while solar energy created even more at over 260,000 jobs,

254. Id. at Adults Reporting Physical Inactivity.

255. Id. at Adults Who Smoke.

256. See Hopkins, supra note 2.

257. See Li \& Gibson, supra note 194, at 10019 (discussing North Carolina's piedmont region).

258. See Andrews, supra note 189 , at 883.

259. Li \& Gibson, supra note 194, at 10025.

260. Hoppock, supra note 211 , at 3.

261. Benefits of Renewable Energy Use, Union Concerned Scientists (Dec. 20, 2017) https://www.ucsusa.org/clean-energy/renewable-energy/public-benefits-of-renewable-power\#bftoc-3 [https://perma.cc/RD3U-P6Y9].

262. Id. 
and to "contrast, the entire coal industry employed 160,000 people."263 The renewable energy sector needs employment that includes manufacturing, development, transportation and maintenance among others. ${ }^{264}$ This resulted in more than 500 factories manufacturing parts for wind turbines in the United States in 2016, which "represented $\$ 13.0$ billion in investments." ${ }^{265}$ This, in turn, would also benefit Indiana and local governments by replacing income from property and income taxes from coal mines with those taxes from a greater number of residents and facilities. ${ }^{266}$ This is just a small analysis of the economic benefits of renewable energy, but with other states and countries throughout the world making the transition, it would be beneficial for Indiana to do the same, and do so with increased economic, public health, and environmental benefits.

263. Id.

264. Id.

265. Id.

266. Id. 